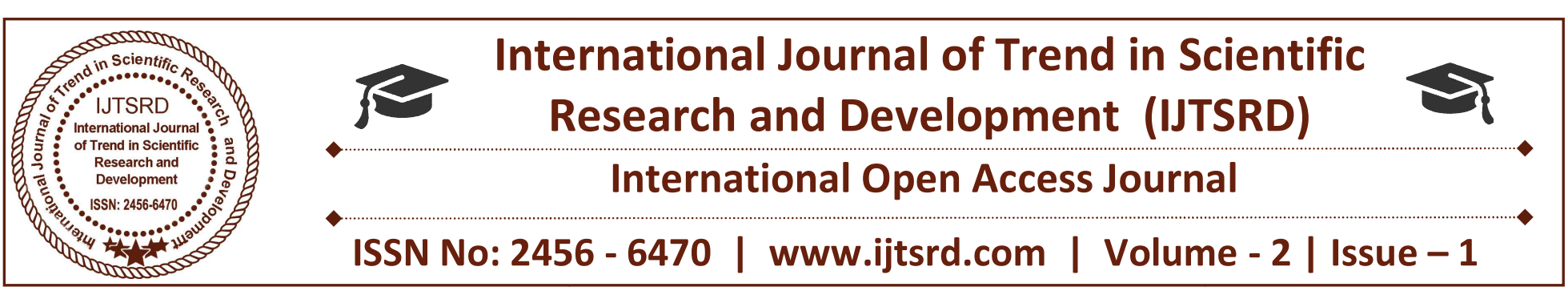

\title{
Corporate Leadership: A Study of Cultural Diversity Skills in Growing in the Corporate World
}

\author{
Prof. Dr. Satya Subrahmanyam \\ Head and Managing Partner, Department of Business Management, \\ Vignan Institute of Technology and Management, Berhampur, Odisha, India
}

\section{BACKGROUND}

Since corporate leaders are responsible for the overall direction and strategic vision of their corporate, it is essential they understand the shared values, assumptions and beliefs of the followers and counterparts they influence, especially in cross cultural corporate (Schein, 2004). Chin, Gu and Tubbs (2001) emphasized this need by stating, contingency theories of corporate leadership have taught us that corporate leaders are only effective in relation to particular context. Hence, corporate leaders must change their behaviour in relationship to the context (Chin et al., 2001).

In order to understand how to effectively change behaviour, corporate leaders must examine how their own behaviour and culture differs from the behaviour and culture of their followers and counterparts (Harris, Moran \& Moran, 2004). In addition, a corporate leader's upbringing the experience are instrumental in formulating cultural values, which will influence their attitudes and bahaviours in ways that may not be conscious (Yukl, 2006). Moreover, corporate leaders use their power and influence to shape corporate culture (Ferrell, Fraedrich \& Ferrell, 2009). Thus, if corporate leaders are not aware of their own ingrained behaviours, norms and values and how they can interact and conflict with the behaviours, norms and values of other cultures, it can be inferred that there is a potential for their actions and decisions to have a negative multiplying effect on the cross cultural corporate they lead (Mancheno-Smoak, Endress, Potak \& Athanasaw, 2009).
It is important to research cross cultural corporate leadership characteristics for several reasons (Dorfman, 1996; House, Wright \& Aditya, 1997). Yukl (2006) summarised the benefits as well. First, the increased globalisation of cross cultural corporate make it more important to learn about effective corporate leadership in different cultures. Corporate leaders in these types of corporate are routinely confronted with the need to build relationships and influence people from different cultures and certain regions of the world. Yukl (2006) supported the previous statement by explaining that corporate leaders must be able to understand how people from different cultures view them and interpret their actions and vice versa. Failure to understand the perspective of foreign counterparts, can often contribute to misunderstood intentions, altered perceptions and in many instances significantly impact mutual expectations and outcomes (Kron, 2007). Lastly and most importantly, cultural values and traditions can influence the attitudes and behaviour of managers in a number of different ways (Yukl, 2006).

\section{Statement of the Problem}

The rapid onset of globalisation has forced many corporate to rethink their cognitive map for interfacing with followers and associates from different cultures (McCall \& Hollenbeck, 2002). As a result, it would appear it is more important than ever for cross cultural corporate to prepare its members to operate and lead in environments distinctively different from their own. 


\section{Purpose of the Study}

The purpose of this study was to provide more insight on the relative importance of the essential cross cultural corporate leadership competencies identified in the literature review. This article accomplished that purpose by investigating the essential cross cultural corporate leadership competencies, characteristics and desired behaviours of corporate leaders. These competencies and behaviours are required to successfully lead and influence followers and host nation counterparts in cross cultural corporate. This study utilised quantitative questionnaire to access and analyse the relative importance and effectiveness of the cross cultural corporate leadership competencies of the corporate. The specific research population was the corporate leaders across the globe.

\section{Significance of the Study}

Corporate leaders need the skills and wisdom to lead cross cultural followers effectively in multicultural environments. In order to prepare corporate leaders to serve, it has been suggested that extensive development in cross cultural corporate leadership is needed to improve the chances of success. This study was intended to provide more insight on the relative importance of the essential cross cultural corporate leadership competencies identified in the literature review. As a result of this study, the field of corporate leadership will have a better understanding of the competencies and behavioural characteristics that successful corporate leaders operating in cross cultural corporate and diverse environments should possess.

The relevant theories related to this study include cross cultural competency, cross cultural corporate leadership and leadership. This study was designed to provide insight related to cross cultural corporate leadership characteristics and desired behaviours inside a cross cultural environment.

\section{Research Questions}

This study attempted to answer the following research questions, evolved from the problem statement:

1. What level of cross cultural competency do corporate leaders serving in multinational corporate possess?

2. Which specific cross cultural corporate leadership competencies are exceptional and inadequate and how does the presence or absence of these competencies affect corporate leaders?

Ho: The corporate leaders do possess an adequate or better level of cross cultural competencies.

Ha: The corporate leaders do not possess an adequate level of cross cultural competencies.

\section{Definition of Terms}

Throughout the study, the following definitions are provided to facilitate common understanding:

Cross cultural Corporate Leadership: Cross cultural corporate leadership is defined as the corporate leader's ability to achieve the corporate mission while maintaining the capability of operating effectively in a global environment while being respectful of cultural diversity. This is an individual who can manage accelerating change and differences. The global (cross cultural ) corporate leader is open and flexible in approaching others, can cope with situations and people disparate from his or her background and is willing to re-examine and alter personal attitudes and perceptions (Harris et al., 2004).

Cultural Awareness: The act of understanding the need to consider cultural terrain and using the information extrapolated from the environment in decision making (Wunderle, 2008).

Cultural Competency: The term cultural competency refers to the ability to use one's knowledge, experience and skill to facilitate communication and skill acquisition across cultures (Barrera \& Corso, 2002).

Cultural Intelligence: Cultural Intelligence (CQ) is defined as a person's capability to function effectively in situations characterised by cultural diversity (Earley \& Mosakowski, 2005)

Culture: Culture is the customary values, beliefs, norms, perceptions and behaviours learned and practiced by members of a collective society (Dahl, 2004).

Globalisation: Globalisation is the creation or expansion of an identifiable network around the globe, which enables people to connect and operate across transnational distances and cultural domains (Allison, 2000). 
Global Mindset: Global mindset is the skill of combining openness, flexibility and awareness of diversity across cultural domains with the propensity and ability to synthesize across this diversity (Gupta \& Govindarajan, 2002).

Corporate Leadership: Corporate leadership is the art of skilfully influencing and motivating others to wilfully accomplish the mission or achieve a set of goals (U.S. Air Force, 2001).

\section{Literature Review}

Within the past century, over 350 definitions have been created to help define the concept of corporate leadership (Daft, 2007) and yet, no one has been able to define corporate leadership with precision, accuracy and conciseness so that people are able to label it correctly when they see it happening or when they engage in it (Rost, 1992). Despite the vast array of corporate leadership research literature, a consensually agreed upon definition for corporate leadership or even cross cultural corporate leadership among scholars still does not exist (Bass, 1990).

Furthermore, since definitions of corporate leadership vary in terms of emphasis on leader abilities, personality traits, influence relationships, cognitive versus emotional orientation, individual versus group orientation and appeal to self versus collective interest (House et al., 1997). Scholars and practitioners have been unable to identify a single element or combination of elements that thoroughly define the characteristics of corporate leadership. As result, numerous theories have emerged to categorise the attributes associated with the concept of cross cultural corporate leadership.

\section{GLOBE Research Project}

One major research discovery for the field of cross cultural corporate leadership is the Global Leadership and Organisational Behaviour Effectiveness (GLOBE) Project. The Javidan and Hauser (2004) research on the GLOBE survey was instrumental in identifying numerous dimensions and behaviours essential to successful cross cultural corporate leadership. For instance, the authors indicated that the GLOBE survey offers the following nine independent variables or cross cultural dimensions:

Uncertainty Avoidance - Extent corporate or countries feel threatened by uncertain the unknown situations (Hofstede, 2001).
* Power Distance - The extent followers in cross cultural corporate or countries are willing to accept that superiors have more power (Hofstede, 2001).

* Institutional Collectivism - The degree to which individuals of a particular culture and cross cultural corporate encourage and reward collective distribution of resources (Triandis, 1995; Hofstede, 2001).

* Group Collectivism - The degree to which individuals of a particular culture express pride, loyalty and cohesiveness (Triandis, 1995).

- Assertiveness - The degree to which individuals of a particular culture expresses assertiveness (Hofstede, 2001).

* Gender Egalitarianism - The degree to which cross cultural corporate, countries and societies promote gender equality (Hofstede, 2001).

* Future Orientation - The degree to which individuals of a particular culture engage in planning of future activities (Kluckhohn \& Strodtbeck, 1961).

* Performance Orientation - The degree to which cross cultural corporate or society rewards performance (McClelland, 1961).

* Humane Orientation - The degree to which cross cultural corporate and societies reward fairness and are friendly, altruistic and generous to others (Kluckhohn \& Strodtbeck, 1961).

In addition, Javidan's and Hauser's (2004) analysis of the GLOBE survey was instrumental in helping the authors to identify the following six cross cultural corporate leadership characteristics:

* Charismatic / Value Based Leadership - The ability for a leader to inspire and motivate followers (refer to transformational leadership).

* Team-Oriented Leadership - The ability to build common purpose among members of a team.

* Participative Leadership - The degree to which followers are involved in decision making.

* Humane-Oriented Leadership - The ability to exhibit compassion and generosity in leadership.

* Autonomous Leadership - A leadership style, which relies on individualistic and independent attributes.

- Self-Protective Leadership - A leadership style, which promotes safety and security of a group or corporate.

Early and Ang (2003) referenced James Q. Wilson's research on morality and ethics as a good source for understanding the essential values needed for cultural 
competency: sympathy, fairness, self-control and duty. The authors also highlighted the Riggio, Maessamer and Throckmorton social intelligence base model and its following associated skills as a good approach for understanding cross cultural corporate leadership competencies:

* Expressivity - encoding messages and interaction.

* Sensitivity - decoding messages and interpreting cultural norms and roles.

* Control - controlling emotions (Early \& Ang, 2003).

\section{Project Management Dimension}

Trompenaars and Hampden-Turner (1998) highlighted the findings from their cross cultural training programs, as well as their research of managers (corporate leaders) from 30 different corporate operating in over 50 countries. Their research describes the cultural differences in the following five dimensions:

* Universalism Versus Particularism - Universal rights compared to the rights of the individuals.

* Communitarism Versus Individualism - Selfinterest versus interests of the entire community.

* Neutral Versus Emotional - Objectivity and detachment versus effusiveness and expressiveness.

* Diffuse Versus Specific - Low context versus high context.

* Achievement Versus Ascription - Individual performance compared to position.

\section{Virtual Teams Dimensions}

The research of Jarvenpaa, Knoll and Leidner (1998) focused on the dimension of trust in a global virtual team setting. The authors' research of 75 teams operating in different countries revealed that the existence of trust among team members enables followers to take risk without fear of reprimand (Kramer \& Tyler, 1996). Lastly, Jarvenpaa et al., (1998) identified four perspectives for researching the competency of trust:

* Individual personality differences (Frost, Simpson \& Maughan, 1978).

* Institutional Phenomenon (Lewis \& Weigert, 1985; Sitkin \& Roth, 1993).

* Cross cultural issues (Farris, Senner \& Butterfield, 1973).

* Interpersonal relations (Cummings \& Bromiley, 1996).

\section{Mendenhall et al., Core Cross Cultural Corporate Leadership Dimensions}

Mendenhall et al., (2008) conducted research on cross cultural corporate leadership literature and its associated competencies. The authors' literature review revealed, social scientists have delineated over fifty competencies that influence global leadership effectiveness. However, many of these competencies overlap conceptually and are often separated only by semantic differences in the labels given them by the researcher. As a result, the authors were able to group the numerous competencies found within the literature review into six core dimensions: a). Cross cultural relationship skills, b). Traits and values, c). Cognitive orientation, d). Global business expertise, e). Global organising expertise and f). Visioning.

Mendenhall et al., (2008) further summarised the competencies into three broad facets or dimensions for individuals: a). The cognitive / perceptual, b). Other / relationship and c). Self / self-efficacy domains.

\section{Essential Cross Cultural Corporate Leadership Roles}

Another way scholars have investigated cross cultural corporate leadership competencies is through the concept of roles. Rosen, Digh, Singer and Phillips (2000) studied over 75 CEOs and 1,058 participants operating in 18 different countries. The authors presented several different views of cultural intelligence (CQ), which they referred to as global literacy. Rosen et al., also described roles essential for cross cultural corporate leadership such as proud ancestor (understanding and appreciating heritage), inquisitive nationalist (insatiable curiosity for foreign cultures), respectful moderniser (learning how to apply elements of other cultures to own culture), cultural bridger (celebrating commonalities of foreign cultures and overcoming differences and global capitalist (balancing capitalism and social responsibility in a global business platform).

\section{Common Sense Competencies}

Peterson (2004) identified the following 11 common sense traits or competencies that can lead to success for cross cultural corporate leaders: 1. Cultural selfawareness, 2. Cultural awareness of others, 3. Cultural sensitivity, 4. Cross cultural communication skills, 5. Tolerance for ambiguity, 6. Flexibility, 7. Openmindedness, 8. Humility, 9. Empathy, 10. Outgoing 
personality and 11. Self-reliance. Peterson suggested that cross cultural corporate leaders should focus on the traits they perceive as weaknesses and develop an action plan to transform their weaknesses into strengths.

\section{Desired Mental Characteristics}

Jokinen et al., (2005) provided a detailed review and analysis of existing cross cultural corporate leadership and other related literature. The major benefit of this research is that it incorporated the main findings of previous research into a comprehensive framework of cross cultural competencies. Most importantly, the findings provided a starting point for practitioners in the field of cross cultural corporate leadership training. The authors identified the following list of fundamental cross cultural corporate leadership competencies: selfawareness (self-management), engagement in personal transformation and inquisitiveness.

In addition, the research of Jokinen et al., (2005) provides a list of desired mental characteristics that cross cultural corporate leaders should possess. The following is a list of desired mental characteristics for cross cultural corporate leaders: Optimism, self regulation, social judgement skills, empathy, motivation to work in an international environment, cognitive skills and acceptance of complexity and its contradictions.

\section{Measures of Cross Cultural Corporate Competence}

In response to the need for cross cultural corporate leadership competence, many scholars and corporate have invested considerable resources to develop measures and tools needed to develop their corporate leaders. The following section will provide synopsis of these measures based on the following cross cultural corporate competence constructs: a. Multi-dimensional, b. Developmental, c. Trait-based, d. Behaviour and e. Others.

\section{Cross Cultural Corporate Competence as a Multi- dimensional Construct}

Several examples of this construct are seen in the evaluation of cultural intelligence (CQ), which analyses a person's ability to function in culturally diverse situations and the Munroe Multicultural Attitude Scale Questionnaire (MASQUE).

\section{Cultural Intelligence (CQ)}

CQ is defined as a person's capability to function effectively in situations characterised by cultural diversity (Ang et al., 2005). To further explain, CQ can provide corporate leaders with insight into their own personal capabilities, which are instrumental in helping them to cope, perform and lead followers from different cultures in cross cultural corporate. Thus this measurement is accomplished through the incorporation of the four dimensions in the CQ scale: cognitive, behavioural, motivational and strategic (meta-cognitive) (Earley \& Ang, 2003).

\section{Multicultural Attitude Scale Questionnaire (MASQUE)}

The MASQUE is another multi-dimensional construct tool, which uses a set of dimensions similar to CQ (Munroe \& Pearson, 2006). However, in addition to covering the CQ dimensions, the MASQUE includes subscales such as knowing, caring and acting. Furthermore, the MASQUE covers broader cultural topics different from CQ such as gender, race, sexual orientation and socioeconomic status.

\section{Cross Cultural Corporate Competence as a Development Construct}

The intercultural Development Inventory is (IDI) an example of a developmental construct measurement tool, which can access a potential cross cultural corporate leader's subjective experiences of cultural differences. The IDI uses the developmental model of intercultural sensitivity as a foundation to determine whether a corporate leader has more of an ethnocentric or an ethno relative orientation towards culture (Bennett, 1993).

\section{Cross Cultural corporate Competence as Trait- based}

The cross cultural corporate competence as a traitbased category consists of measures and measurement tools that access the personality traits of corporate leaders with the objective of identifying essential predicators of cross cultural corporate effectiveness (Mastumoto et al., 2001).

\section{Multicultural Personality Questionnaire (MPQ)}

Another of a tool, which can help access cross cultural corporate leadership competencies, is the MPQ. The 
MPQ uses the following personality trait subscales to access a corporate leader's cultural competency: empathy, emotional stability, social initiative, openmindedness and flexibility (Van der Zee \& can Oudenhoven, 2001).

\section{Intercultural Adjustment Potential Scale (ICAPS)}

The ICAPS uses the following personality trait subscales to access a corporate leader's cultural competency: emotion regulation, openness, flexibility and creativity (Matsumoto et al., 2001).

\section{Cross Cultural Adaptability Inventory (CCAI)}

The CCAI is comprised of subscales from both the trait (flexibility, emotional resilience, personal autonomy) and skill (perceptual acuity) categories (Kelley \& Meyers, 1995). This tool is heavily used in measuring the outcome of training programs. However, there appears to be little to no evidence of the CCAI's validity in the literature. Also, despite frequent use in training programs, the CCAI lacks sufficient evidence to warrant further use (Abbe et al., 2007).

\section{Cross Cultural Corporate Competence as Behavioural Aspect}

Scholars have also developed tools to access cross cultural corporate competence for the behavioural aspect. Behavioural measures assess cross cultural behaviours that enable corporate leaders to be successful in cross cultural settings and corporate (Hammer, 1987). Most importantly, the behaviour measures competencies that facilitate effective communication (Martin \& Hammer, 1989).

\section{Other Measurement Approaches}

Other measurement tools using different approaches have been developed in response to the increase in cross cultural corporate leadership research like Situational Judgement Test for Cross Cultural Interactions (CCSI SJT) (Ascalon, 2005); Cross Cultural Adaptability Scale (CCAS) (Vanderpool, 2002) and Global Competencies Inventory (GCI) Mendenhall et al, 2008).

\section{Cultural Diversity and Corporate Leadership}

Hofstede (2001) assets that ideas about corporate leadership reflect the dominant culture of a country or region. Corporate leaders are often seen as cultural heroes and set the standard for desired behaviours.
Therefore, leading across multiple cultures can be quite challenging. It is important for cross - cultural leaders to understand various cultures and develop the appropriate cultural skills. Cross - cultural leaders are defined as those that transcend different cultures and bring people together that have different cultural backgrounds (Graen, Hui, Wakabayashi \& Want, 1997).

Culturally intelligent leaders are skilful at recognizing behaviours that are driven by culture. Researchers agree that leaders can develop strategies over time that will help them meet the challenges of working in a new culture and improve their own cultural intelligence. Early and Ang (2003) outlined four facets of cultural intelligence.

The first is the Meta - cognitive, where an individual is culturally aware during interactions with someone from a different cultural background.

* The second facet is the cognitive, which refers to general knowledge about a culture.

* The third facet is the motivational, which refers to the amount of energy and the direction of that energy towards learning about the functioning in cross - cultural situations.

* The last facet is called behavioural, which is described as the capability to use appropriate verbal and non - verbal actions when interacting with someone from a different culture.

Cohen (2010) indicated that a global leadership mindset carefully balances a dichotomy of global standardization versus local customization. According to Clapp - Smith (2009) a global mindset as the basis for a cultural paradigm in making judgements about a situation, the basis of producing culturally appropriate behaviour and a frame for a cognitive reference point. A global mindset consists of openness to self, others and context, which brings awareness of diverse cultural viewpoints and which leads to correct judgement of situations in the fast changing corporate world.

Maznevski and Zander (2001) stated that a multicultural leader should act as a cultural interpreter, which explains as an innovator by creating new and different ways of looking at problems, by going beyond formal ways of thinking in a particular culture and by generating new ideas coming from different a worldview and value system so that culturally diverse view point are reflected. 
Zayani (2008) stated the characteristics of paradox multicultural leaders face paradox in their daily routine due to dealing with opposing ideas coming from contradicting worldviews. Fisher-Yoshida and Geller (2009) reiterated that cultural differences bring paradoxical issues that are unavoidable for multicultural leaders facing opposing concepts. Co existence of cultural diversity requires respect for different cultures and embracing different cultural frameworks and new perspectives. These paradoxes present a dilemma to a corporate leader who may need to balance widely contrasting values while presenting any assets the paradoxes can bring about.

In addition to the cultural differences, there might be opposing demands coming from headquarters, the host - country and the local situation (Gannon, 2008; Mendenhall, 2001). In processing power for their role, there is a tension on overplaying or downplaying to acquire information or progress the work. The corporate leaders need to understand the host-country nationals, but sometimes, not knowing them or taking advantage of them may bring more benefit to the organisation.

In any culture, cultural knowledge can aid corporate leaders in a wide variety of tasks, including communicating a vision or strategy, motivating employees, evaluating potential future leaders and creating alignment within an organisation. Corporate leaders working in a culturally diverse environment ignore these cultural variables at their own peril (Gundling et al., 2011).

\section{Methodology}

There are two principal research paradigms can be used in business research, namely - the positivistic and a phenomenological / interpretivism paradigm. According to Bryman and Bell (2007), positivism is an epistemological position that advocates the application of the methods of the natural sciences to the study of social reality and beyond. The role of positivism as stated by Anderson (2004) resides in searching for facts in terms of clarifying the relationship between variables before identifying a data collection pattern through statistical approaches as followed in quantitative research procedures. According to Collis and Hussey (2003), the positivistic approach concentrates on facts and the causes of social events, paying modest respect to the subjective state of the individual.
The quantitative research is built on a numerical measurement of specific characteristics relation to a phenomenon. Quantitative approaches employ deductive logic, moving from the general to the specific. The tools used to carry out quantitative research tend to be surveys and questionnaires (Coombes, 2001). It is a very structured approach and is most often focused on objectivity, generalisability and reliability (Collis \& Hussey, 2003). The key advantage of the quantitative approach, therefore, is that it is based on fact and reliable data that enables researchers to generalize their findings to the population from which the sample has been drawn.

A non-experimental research design is an appropriate approach to determine if a specific treatment (cross cultural understandings of a corporate leader) influences an outcome (corporate leadership skills and effectiveness of the corporate) using a sample that is not randomly assigned to a treatment or comparator group (Creswell, 2014).

A questionnaire according to Collis and Hussey (2003) can be used to gather data, when the issues which arise are likely to be confidential and sensitive and give respondents more time to consider their answers. The questionnaire survey, as defined by McDaniel and Gates (2002) is comprised of a set of questions designed to generate the evidence necessary to accomplish the objectives of the research study. It is a method of getting answers to the research questions based on designing specific questions to be answered by the research participants (Robson, 2004; Bryman, 2004). Questionnaires as a survey method may be viewed as a comparatively simple and uncomplicated means of examining participants' attitudes, values, beliefs and motives. When the survey includes sensitive issues, a questionnaire affords a high level of confidentiality and anonymity (Robson, 2004).

The questionnaire consisted of five close-ended questions with an open-ended section at the end of the questionnaire for participants to add any further comments about their perception on the Cross Cultural Corporate Leadership Skills. The response scales took the form of the Likert Scale. The Likert scale is one of the most widely used response scales in research and is used to evaluate behaviour, attitude or other phenomenon on a continuum. Rating scales simplify and more easily quantify peoples' behaviours or attitudes (Leedy \& Ormrod, 2005). A neutral response option has not been given which might prove a bit disastrous if the majority of the respondents decide to 
choose this, thus posing a danger of not being able to conduct an optimal evaluation.

The sample size is a significant characteristic with any empirical study in which the goal is to make assumptions about a population based on a sample. Indeed, the sample size used in the study was determined based on the data collection figures and the need to obtain sufficient statistical power (Saunders et al., 2009). Saunders et al., added that the larger the sample size, lower the likely error in generalizing to the population.

The survey was distributed to a purposeful sample of 300 participants includes corporate leaders from different spectrum, represents different areas of specialization and comprises different sectors. Statisticians contend that as a sample size increases, variability (i.e., effort variance) decreases and power increases. As power increases to detect a false null hypothesis, there is an increased risk of falsely rejecting a true null hypothesis.

\section{Analysis}

The survey asked a series of questions in order to establish whether there is a relationship between cultural diversity skills of a corporate leader and the effectiveness of the corporate. The focus of the research and the survey is to find out whether the prominence of cultural diversity skills is increasing in the growing corporate world. This section provides a summary of the information that was collected through a questionnaire. The following tables and figures provide a snapshot of cultural diversity skills of corporate leader.

Table 4: Beliefs, Customs, Norms and Values

\begin{tabular}{|c|l|c|c|c|c|c|c|}
\hline \multirow{2}{*}{} & \multicolumn{2}{|c|}{ Indicator } & \multicolumn{3}{|c|}{ Non-Agree } & \multicolumn{3}{c|}{ Agree } \\
\cline { 3 - 8 } & $\begin{array}{l}\text { Strongly } \\
\text { Disagree }\end{array}$ & $\begin{array}{c}\text { Dis- } \\
\text { Agree }\end{array}$ & Total & Agree & $\begin{array}{c}\text { Strongly } \\
\text { Agree }\end{array}$ & Total \\
\hline 4 & $\begin{array}{l}\text { In your opinion, a leader tries to understand } \\
\text { prevailing beliefs, customs, norms and values } \\
\text { of multicultural groups. }\end{array}$ & 66 & 66 & 132 & 78 & 90 & 168 \\
\hline
\end{tabular}

Survey respondents were asked whether a corporate leader should try to understand prevailing beliefs, customs, norms and values of multicultural groups. A good number of respondents which consists around $56 \%$ agreed to the opinion that a corporate leader should try to understand beliefs, customs, norms and values of multicultural groups.

Figure 4: Beliefs, Customs, Norms and Values

\section{Cultural Diversity Skills}

$\square$ Strongly Disagree $\quad$ Disagree $\quad$ Agree $\square$ Sgrongly Agree

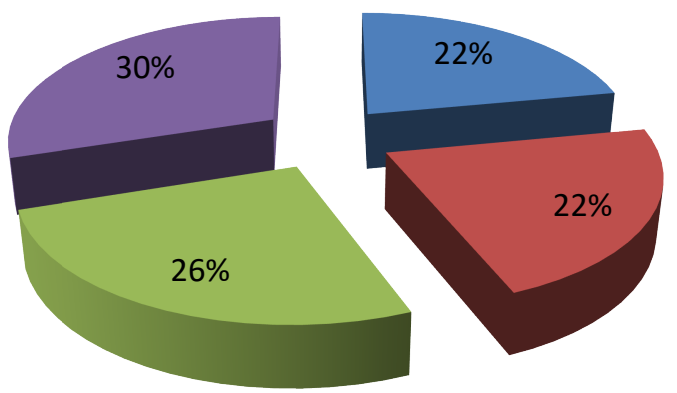


Table 5: Collaborative Team

\begin{tabular}{|c|l|c|c|c|c|c|c|}
\hline \multicolumn{2}{|c|}{ Indicator } & \multicolumn{3}{|c|}{ Non-Agree } & \multicolumn{3}{c|}{ Agree } \\
\cline { 3 - 8 } & $\begin{array}{l}\text { Strongly } \\
\text { Disagree }\end{array}$ & $\begin{array}{c}\text { Dis- } \\
\text { Agree }\end{array}$ & Total & Agree & $\begin{array}{c}\text { Strongly } \\
\text { Agree }\end{array}$ & Total \\
\hline $\mathbf{5}$ & $\begin{array}{l}\text { In your opinion, a leader initiates for a } \\
\text { collaborative team that shares a common goal } \\
\text { and works well together. }\end{array}$ & 36 & 126 & 162 & 66 & 72 & 138 \\
& $(12)$ & $(42)$ & $(54)$ & $(22)$ & $(24)$ & $(46)$ \\
\hline
\end{tabular}

Survey respondents were asked whether a corporate leader should take initiation for a collaborative team that shares a common goal and works well together. For a surprise, around $54 \%$ of respondents expressed their negative response for the indicator which expresses that a corporate leader should initiate the formation of collaborative teams in a cultural diversified working environment.

Figure 5: Collaborative Team

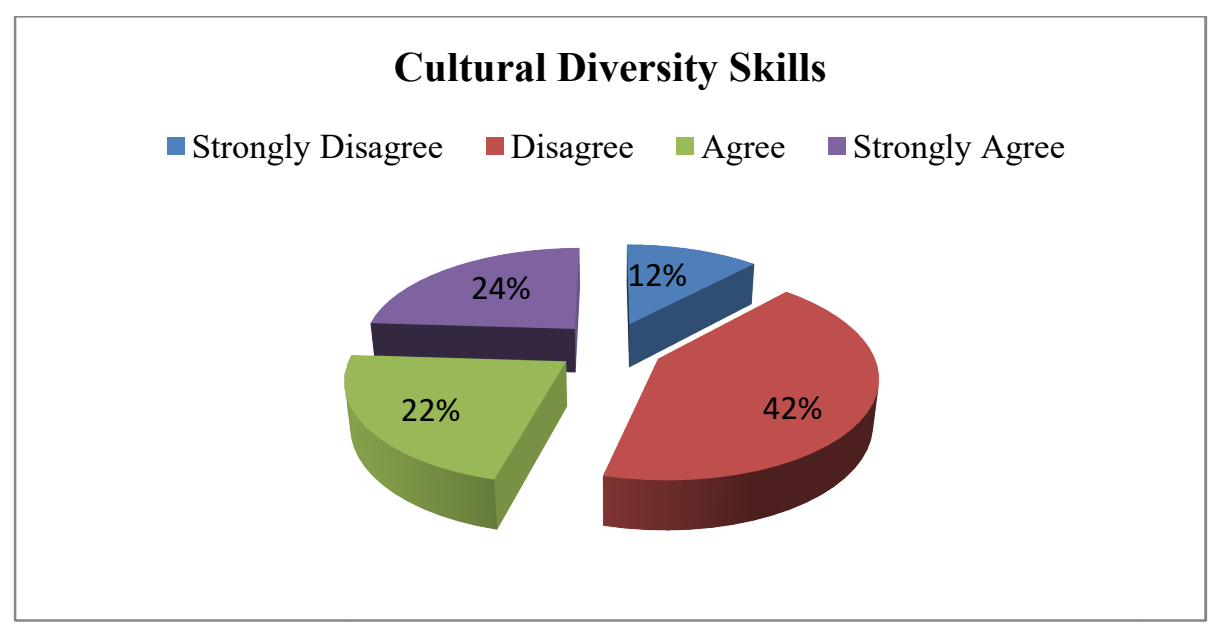

The table 6 provides the data showing of these different aspects of the Cultural Diversity Skills of corporate leadership. It is observed that overall 239 per cent of the participants did not agree and 261 per cent agreed. Out of 239 per cent of not agreed the highest percent denied i.e. 54 percent in the aspects of a leader initiates for a collaborative team that shares a common goal and works well together. And out of overall 281 percent of agreed respondents 56 per cent are agreed in the aspects of a leader try to understand prevailing beliefs, customs, norms and values of multicultural groups. 
Table 6: Cultural Diversity Skills

\begin{tabular}{|c|c|c|c|c|c|c|c|}
\hline & \multirow[t]{2}{*}{ Indicator } & \multicolumn{3}{|c|}{ Non-Agree } & \multicolumn{3}{|c|}{ Agree } \\
\hline & & $\begin{array}{l}\text { Strongly } \\
\text { Disagree }\end{array}$ & $\begin{array}{l}\text { Dis- } \\
\text { Agree }\end{array}$ & Total & Agree & $\begin{array}{l}\text { Strongly } \\
\text { Agree }\end{array}$ & Total \\
\hline 1 & $\begin{array}{l}\text { In your opinion, a leader understands well the } \\
\text { ambiguity and stress often result from } \\
\text { multicultural situations, because people are } \\
\text { not sure what to expect from each other. }\end{array}$ & $\begin{array}{l}48 \\
(16)\end{array}$ & $\begin{array}{l}96 \\
(32)\end{array}$ & $\begin{array}{l}144 \\
(48)\end{array}$ & $\begin{array}{l}42 \\
(14)\end{array}$ & $\begin{array}{l}114 \\
(38)\end{array}$ & $\begin{array}{l}156 \\
(52)\end{array}$ \\
\hline 2 & $\begin{array}{l}\text { In your opinion, a leader fosters a culture of } \\
\text { transparency and honest communication. }\end{array}$ & $\begin{array}{l}33 \\
(11)\end{array}$ & $\begin{array}{l}105 \\
(35)\end{array}$ & $\begin{array}{l}138 \\
(46)\end{array}$ & $\begin{array}{l}78 \\
(26)\end{array}$ & $\begin{array}{r}84 \\
(28)\end{array}$ & $\begin{array}{l}162 \\
(54)\end{array}$ \\
\hline 3 & $\begin{array}{l}\text { In your opinion, a leader is able to describe } \\
\text { the cultural or community strengths of } \\
\text { multicultural groups. }\end{array}$ & $\begin{array}{l}51 \\
(17)\end{array}$ & $\begin{array}{l}90 \\
(30)\end{array}$ & $\begin{array}{l}141 \\
(47)\end{array}$ & $\begin{array}{l}81 \\
(27)\end{array}$ & $\begin{array}{c}78 \\
(26)\end{array}$ & $\begin{array}{l}159 \\
(53)\end{array}$ \\
\hline 4 & $\begin{array}{l}\text { In your opinion, a leader tries to understand } \\
\text { prevailing beliefs, customs, norms and values } \\
\text { of multicultural groups. }\end{array}$ & $\begin{array}{l}66 \\
(22)\end{array}$ & $\begin{array}{l}66 \\
(22)\end{array}$ & $\begin{array}{l}132 \\
(44)\end{array}$ & $\begin{array}{l}78 \\
(26)\end{array}$ & $\begin{array}{l}90 \\
(30)\end{array}$ & $\begin{array}{l}168 \\
(56)\end{array}$ \\
\hline 5 & $\begin{array}{l}\text { In your opinion, a leader initiates for a } \\
\text { collaborative team that shares a common goal } \\
\text { and works well together. }\end{array}$ & $\begin{array}{l}36 \\
(12)\end{array}$ & $\begin{array}{l}126 \\
(42)\end{array}$ & $\begin{array}{l}162 \\
(54)\end{array}$ & $\begin{array}{l}66 \\
(22)\end{array}$ & $\begin{array}{l}72 \\
(24)\end{array}$ & $\begin{array}{l}138 \\
(46)\end{array}$ \\
\hline & Total & $\begin{array}{l}234 \\
(78) \\
\end{array}$ & $\begin{array}{r}483 \\
(161) \\
\end{array}$ & $\begin{array}{r}717 \\
(239) \\
\end{array}$ & $\begin{array}{r}345 \\
(115)\end{array}$ & $\begin{array}{r}438 \\
(146) \\
\end{array}$ & $\begin{array}{r}783 \\
(261) \\
\end{array}$ \\
\hline
\end{tabular}

Note: The figures given in parentheses indicate percentages of participants and non-participants. The value of Chisquare $\left(\chi^{2}\right)$ is 2.26 between participants with disagree and agree. The table values at 5 per cent with 4 degree of freedom are 9.48 .

Figure: 6 Cultural Diversity Skills
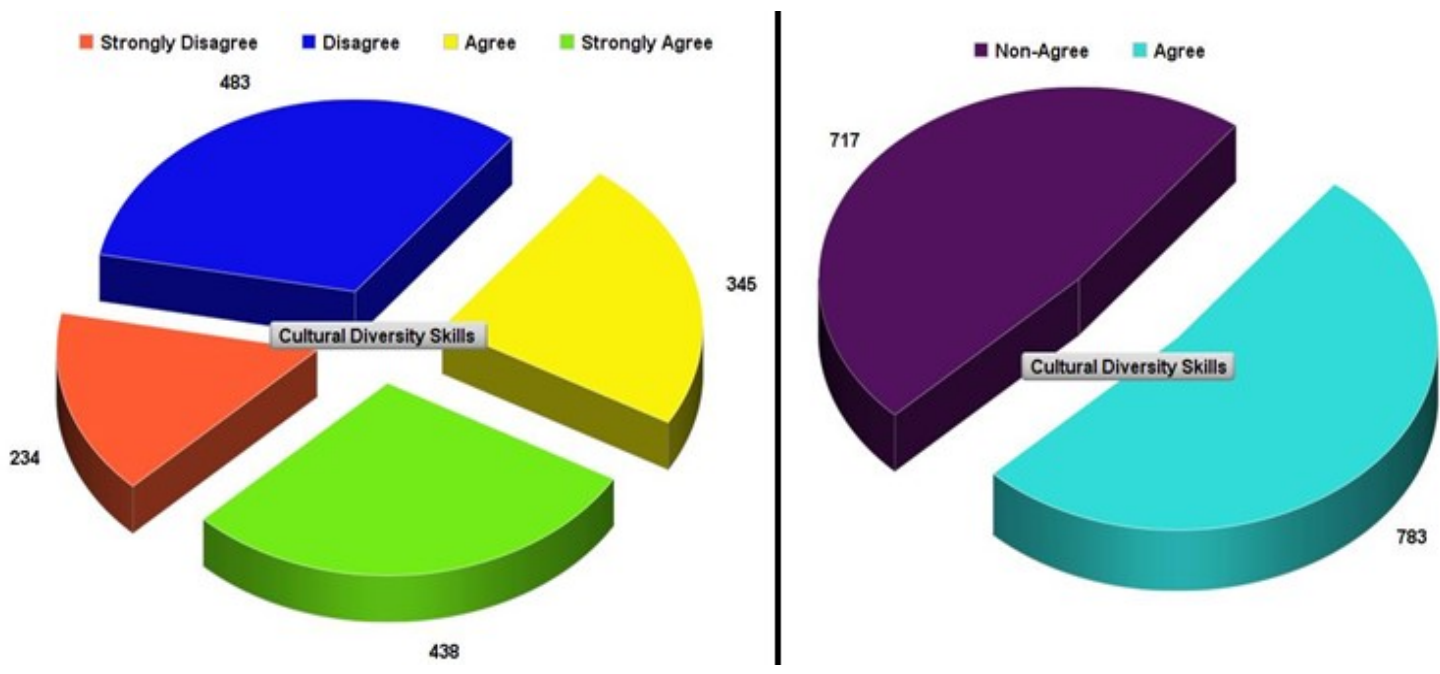
A comparative analysis is made to know the impact of Cultural Diversity Skills, in between agreed participants with the non-agreed participants consisting of different relevant indicators of Cultural Diversity Skills. The significance of difference between agreed participants with the non-agreed participants consisting of different relevant indicators of Cultural Diversity Skills is measured with Chi-square $(\chi 2)$ test. Here, the table value of Chi-square $\left(\chi^{2}\right)$ for 4 degree of freedom at 5\% level of significance is 9.48 whereas the result of $\left(\chi^{2}\right)$ test found to be less than this value. So, there is a significant impact of Cultural Diversity Skills on corporate leadership.

\section{Summary}

One of the key issues facing corporations in this century is the importance of rising of cultural diversity. According to Lavaty and Kleiner (2001), cultural diversity is an essential topic for discussion in the $21^{\text {st }}$ century. Gröschl and Doherty (2006) stated that the increase in cultural diversity in the workforce is due to demographic changes in the population. This increasingly diverse workgroup affects human resource strategies. Therefore, understanding and managing cultural diversity is important for the successful evolution of a modern organisation.

In a globalised economy, mergers and acquisitions have increasingly become more cross - border. However, a mismatched acquisition, where there is a poor cultural fit, will struggle to survive. Culture is a complex and multi - level phenomenon. It includes organisational, industrial, functional, national, occupational, and professional dimensions. Having a strong strategy and framework for managing the cultural integration process is critical to the success of the merged organisation (Mobley et al., 2011). Additionally, a critical success factor to cultural integration is the ability to manage complex networks of relationships (Goldsmith et al., 2003). Organisations regularly interact with culturally diverse suppliers, customers, regulators and employees, either face-to-face or virtually. These situations highlight the importance of cultural intelligence (Clapp - Smith, 2009).

According to Hofstede and Hofstede (2005), culture is the collective programming of mind that distinguishes the members of one group or category of people from another. Culture has something to do with sharing or consensus among the member of a group. The most obvious aspect of such sharing is the common language and conceptual categories that are discovered wherever studies are a social group that has had any kind of history and shared experience (Schein, 2011).

Roberson and Park (2007) maintain that a multicultural workforce results in excellence, achieved by attracting and retaining the best talent. This helps reduce costs associated with turnover, absenteeism and low productivity. A multicultural company can penetrate and widen its markets with knowledge of political, social, legal, economic and cultural environment.

Corporations use multicultural teams to expand globally and to accomplish the potential for cross cultural markets in order to achieve the necessary flexibility, responsiveness and improved resource utilisation to meet the continuous demands of a global corporate context (Mowshowitz, 1997). Scholars investigating cultural diversity highlight that firms with highly diverse teams often produce ideas of higher quality when exploration skills are required (Wolfe, 2010). Amaram (2007) stated that the capabilities of identifying problems and generating solutions in culturally diverse teams are greater than those for homogeneous teams.

Canen and Canen (2002) stressed that it is evident that a multicultural team that shares expectations will facilitate communication and team productivity. Scholars have argued that creativity comes from new ideas, multiple perspectives and the different problem solving styles that members bring to the team (Adler, 2002). Ragins and Gonzales (2003) acknowledge that having cultural diversity may be a key requirement for sustained competitive advantage, due to increased creativity and innovation.

Culture is a complex, multidimensional construct that can be studied on several levels: international, national, regional, business and corporate (Wen-Gheng, ChienHung \& Ying-Chien, 2011). Consequently, the need for leaders who have the ability to motivate, communicate and manage cultural variances is a challenge that is increasing in the case of multinational corporate (Dorfman, et al., 2004). Recently there has been a growing interest in the stream of corporate leadership theory known as "charismatic" (Conger \& Kanungo, 1987), "transformational" (Bass, 1985) and "Visionary" (Bennis \& Nanus, 1985). With a little difference between them (Yulk, 2002), these theories concentrate on leadership behaviours that produce an emotional effect on their followers and can convert emotional attachment to the leaders' values and to the collective (Javidan \& Waldman, 2003). 
Many corporate leaders are now starting to consider that diversity has important bottom - line benefits. Diversity in the workforce can lead to competitive advantage because different viewpoints can facilitate unique and creative approaches to problem - solving; thereby increasing creativity and innovation, which in turn leads to better organisational performance (Allen, Dawson, Wheatley \& White, 2004).

\section{References}

1) Abbe, A., Gulick, L. M. V., \& Herman, J. L. (2007). Cross-cultural competence in army leaders: $A$ conceptual and empirical foundation (Study Report No. A270674). Arlington, VA: United States Army Research Institute for the Behavioral and Social Sciences.

2) Adler, N. J. (2002). International dimensions of organizational behaviour, (4th ed.). Cincinnati, $\mathrm{OH}$ : Southwestern.

3) Allen, R., Dawson, G., Wheatley, K \& White, C.S., 2004. Diversity Practices: Learning Responses for Modern Organisation. Development and learning in organisations, 18 (6), 13-15.

4) Allison, G. (2000). The impact of globalization on national and international security. In R. O. Keohane \& J. S. Nye, Jr. (Eds.), Governance in a globalizing world (pp. 72-85). Washington, DC: Brookings Institution Press.

5) Amaram, D. I. (2007). Cultural Diversity: Implications for Workplace Management. Journal of Diversity Management - Fourth Quarter, 2, (4), 1-6.

6) Anderson, V., 2004. Research Methods in Human Resource Management. London: CIPD.

7) Ang, S., Van Dyne, L., \& Koh, C. (2005). Personality correlates of the four factor model of cultural intelligence. Group \& Organization Management, 31(1), 100-123. doi: $10.1177 / 1059601105275267$

8) Ascalon, M. E. (2005). Improving expatriate selection: Development of a situational judgment test to measure cross-cultural social intelligence (Doctoral dissertation). Retrieved from ProQuest Dissertations and Theses database. (AAT 3148748)

9) Barrera, I., \& Corso, R. M. (2002). Cultural competency as skilled dialogue. Topics in Early Childhood Special Education, 22(2), 103-113. doi: $10.1177 / 02711214020220020501$
10) Bass, B.M. (1985). Transformational leadership: Beyond initiation and consideration. Journal of Management, 16, 693-703.

11) Bass, B.M., 1990. Bass \& Stogdill's Handbook of Leadership: Theory, research, and managerial applications (3rd ed.), New York, The Free Press.

12) Bennett, M. J. (1993). Towards ethnorelativism: A developmental model of intercultural sensitivity. In R. M. Paige (Ed.), Education for the intercultural experience (pp. 21-71). Yarmouth, ME: Intercultural Press.

13) Bennis, W. and Namus, B. (1985). Leaders: The Strategies for taking charge. New York: Harper \& Row.

14) Bryman, A. \& Bell, E., 2007. The process of quantitative research Business research methods $\left(2^{\text {nd }}\right.$ ed.). Oxford: University press.

15) Bryman, A., 2004. Social Research Methods, $\left(2^{\text {nd }}\right.$ ed.). Oxford: OUP.

16) Canen, A. G. and Canen, A. (2002). Innovation Management Education for Multicultural Organisations: challenges and a role for logistics. European Journal of Innovation Management, 5, (2), 73-85.

17) Chin, C. O., Gu, J., \& Tubbs, S. L. (2001). Developing global leadership competencies. Journal of Leadership \& Organizational Studies, 7(4), 20-31. doi:10.1177/107179190100700402

18) Clapp-Smith, R., 2009. Global mindset development during cultural transitions (Doctoral dissertation). Retrieved from ProQuest Dissertations \& Theses database. (UMI No. 3360083).

19) Clapp-Smith, R., 2009. Global mindset development during cultural transitions (Doctoral dissertation). Retrieved from ProQuest Dissertations \& Theses database. (UMI No. 3360083).

20) Cohen, W. A., 2010. Drucker on Leadership. San Francisco, Jossey-Bass.

21) Collis, J \& Hussey, R., 2003. Business Research. New York, Palgrave MacMillan.

22) Conger, J. and Kanungo, R. (1987). Toward a behavioural theory of charismatic leadership in organizational settings. The Academy of Management Review, 12 (4), 637-647. 
23) Creswell, J. W., 2014. Research Methods, (4 ${ }^{\text {th }}$ ed.). Thousand Oaks, CA: Sage.

24) Daft, R. L. (2007). The leadership experience (3rd ed.). Toronto, Ontario: Thomson South-Western.

25) Dahl, S. (2004, January). Intercultural research: The current state of knowledge. Middlesex University Business School Discussion Paper No. 26. Retrieved from http://www.alanisguzman.com/archivoc/Culture.pdf

26) Dorfman, P. W. (1996). International and crosscultural leadership research. In B. J. Punnet \& O. Shenkar (Eds.), Handbook for international management research (pp. 267-349). Oxford, MA: Blackwell.

27) Dorfman, P. W. and House, R. J. (2004). Cultural Influence on Organizational Leadership: Literature Review, Theoretical Rationale, and GLOBE Project Goals, in R. J. House, P. J.

28) Hanges, M. Javidan, P. W. Dorfman and V. Gupta (Eds), Culture, Leadership, and Organizations: The GLOBE Study of 62 Societies (pp. 51-67). CA: Sage, Thousand Oaks.

29) Earley, C. P., \& Ang, S. (2003). Cultural intelligence: Individual interactions across cultures. Stanford, CA: Stanford University Press.

30) Earley, P. C., \& Ang, S., 2003. Cultural intelligence: Individual Interactions Across Cultures. Stanford, Calif.: Stanford University Press.

31) Earley, P.C., \& Mosakowski, E. (2005). Cultural intelligence. Harvard Business Review, 82(10), 139-153. Retrieved from http://hbr.org/magazine

32) Ferrell, O.C., Freadrich, J., \& Ferrell, L. (2009). Business ethics: Ethical decision making and cases (7th ed.). Mason, OH: South-Western Cengage Learning.

33) Fisher-Yoshida, B., \& Geller, K. D., 2009. Transnational Leadership Development: Preparing the next generation for the borderless business world. New York, NY: Amacom.

34) Gannon, M. J., 2008. Paradoxes of Culture and Globalization. Los Angeles, CA: Sage.

35) Goldsmith, M., Greenberg, C. L., Robertson, A., \& Hu-Chan, M., 2003. Global Leadership: The next generation. Upper Saddle River, NJ: Pearson Education, Inc., publishing as Financial Times Prentice Hall.
36) Graen, G. B., Hui, C.,Wakabayashi, M., \& Wang, Z. M., 1997. Cross-cultural research alliances in organizational research: Cross-cultural partnershipmaking in action. In: W. H. Mobley, M. J. Gessner \& V. Arnold (Eds.), Advances in global leadership, 3-26, Stamford, CT: JAI Press.

37) Gröschl, S. \& Doherty, L., 2006. The Complexity of Culture: Using the appraisal process to compare French and British managers in a UK based international hotel organisation. International Journal of Hospitality Management, 25(2), 313 334.

38) Gundling, E., Hogan, T., \& Cvitkovich, K., 2011. What is Global Leadership? 10 key behaviours that define great global leaders. Boston, MA: Nicholas Brealey.

39) Gupta, A. K., \& Govindarajan, V. (2002). Cultivating a global mindset. Academy of Management Executive, 16(1), 116-126. Retrieved from http://www.aomonline.org/aom.asp?id=95

40) Hammer, M. R. (1987). Behavioral dimensions of intercultural effectiveness: A replication and extension. International Journal of Intercultural Relations, 11(1), 65-88. doi:10.1016/01471767(87)90032-0

41) Harris, P. R., Moran, R. T., \& Moran, S. V. (2004). Managing cultural differences: Global leadership strategies for the 21st century (6th ed.). New York, NY: Elsevier Butterworth-Heinemann.

42) Harris, P. R., Moran, R. T., \& Moran, S. V. (2004). Managing cultural differences: Global leadership strategies for the 21st century (6th ed.). New York, NY: Elsevier Butterworth-Heinemann.

43) Hofstede, G. H., 2001. Culture's Consequences: Comparing values, behaviors, institutions and organizations across nations. Thousand Oaks, Calif.: Sage.

44) Hofstede, G., \& Hofstede, J., 2005. Cultures and Organizations: Software of the mind. New York, NY: McGraw-Hill.

45) House, R. J., Wright, N. S., \& Aditya, R. N. (1997). Cross-cultural research on organizational leadership: A critical analysis and proposed theory. In P. C. Earley \& M. Erez (Eds.), New perspectives on international/organizationalpsychology (pp. 535-625). San Francisco, CA: New Lexington Press. 
46) House, R.J. \& Aditya, R.N., 1997. The social scientific study of leadership: Quo vadis? Journal of Management, 23(3), 409-473.

47) Jarvenpaa, S. L., Knoll, K., \& Leidner, D. E. (1998). Is anybody out there? Antecedents of trust in global virtual teams. Journal of Management Information Systems, 14(4), 29-64. Retrieved from http://www.jmisweb.

48) Javidan, M. and Waldman, D. A. (2003). Exploring charismatic leadership in public sector: Measurement and consequences. Public Administration Review, 63(2), 229-242.

49) Jokinen, T., Bond, S., Byers, C., McCarthy, G., \& McCraken, M. (2005). Global leadership competencies: A review and discussion. Journal of European Industrial Training, 29(3), 199-216. doi:10.1108/03090590510591085

50) Kelley, C., \& Meyers, J. (1995). The cross-cultural adaptability inventory. Minneapolis, MN: Pearson Performance Solutions.

51) Kramer, R., \& Tyler, T. R. (1996). Trust in organizations: Frontiers of theory and research. In R. Kramer \& T. R. Tyler (Eds.), Trust in organizations: Frontiers of theory and research (pp. 216-245). Thousand Oaks, CA: Sage.

52) Kron, H. (2007). Cross-cultural considerations for the United States security cooperation in the Middle East. The DISAM Journal of International Security Assistance Management, 29(1), 74-87. Retrieved from

http://www.disam.dsca.mil/pubs/publications.htm

53) Lavaty, S. \& Kleiner, B.H., 2001. Managing and understanding the French employee. Management Research News, 24 (3/4), 45-48.

54) Leedy, P. D., \& Ormrod, J. E., 2005. Practical Research. Upper Saddle River, NJ: Pearson Prentice Hall.

55) Mancheno-Smoak, L., Endres, G. M., Potak, R., \& Athanasaw, Y. (2009). The individual cultural values and job satisfaction of the transformationl leader. Organization Development Journal, 27(3). 9-22. Retrieved

from http://www.odinstitute.org/index.htm

56) Martin, J. N., \& Hammer, M. R. (1989). Behavioral categories of intercultural communication competence: Everyday communicators' perceptions. International Journal of Intercultural Relations, 13(3), 303-332. Retrieved from http://www.elsevier.com/wps/find/journaldescriptio n.cws home/

57) Matsumoto, D., LeRoux, J., Ratzlaff, C., Tatani, H., Uchida, H., Kim, C., \& Araki, S. (2001). Development and validation of a measure of intercultural adjustment potential in Japanese sojourners: The Intercultural Adjustment Potential Scale (ICAPS). International Journal of Intercultural Relations, 25, 483-510. Retrieved from http://www.elsevier.com/wps/find/

58) Maznevski, M. L., \& Zander, L., 2001. Leading global teams: Overcoming the challenge of the power paradox. In M. E. Mendenhall, T. M. Kühlmann, \& G. K. Stahl (Eds.), Eveloping Global Business Leaders: Policies, processes, and innovations, 157-174. Westport, CT: Quorum Books.

59) McCall, Jr., M. W., \& Hollenbeck, G. P. (2002). Developing global executives. Boston, MA: Harvard Business School Press.

60) McDaniel, C. \& Gates, R., 2002. Marketing research: the impact of the Internet. Hoboken, NJ: Wiley.

61) Mendenhall, M. A. (2008). Leadership and the birth of global leadership. In M. A.Mendenhall, J. Osland, A. Bird, G. R. Oddou \& M. Maznevski (eds.), Global leadership: Research, practice and development (pp. 1-18). London: Routledge.

62) Mendenhall, M. E., 2001. Introduction: New perspectives on expatriate adjustment and its relationship to global leadership development. In M. E. Mendenhall, T. M. Kühlmann, \& G. K. Stahl (Eds.), Developing Global Business Leaders: Policies, Processes, and Innovations, 1-16, Westport, CT: Quorum Books.

63) Mobley, W. H., Li, M., \& Wang, Y.(Ed.)., 2011. Advances in Global Leadership, 6, Bingley, United Kingdom: Emerald Group.

64) Mowshowitz, A. (1997). Virtual Organization. Communications of the ACM, 40, (9). 30-37.

65) Munroe, A., \& Pearson, C. (2006). The Munroe multicultural attitude scale questionnaire: A new instrument for multicultural studies. Educational and 202 Psychological Measurement, 66(5), 819834. doi:10.1177/0013164405285542

66) Peterson, B. (2004) Cultural intelligence: A guide to working with people from other cultures. Yarmouth, ME: Intercultural Press. 
67) Ragins, B. R. and Gonzalez, J. A. (2003). Understanding diversity in organizations: Getting a grip on a slippery construct. In J. Greenberg (Ed.), Organizational behavior: The state of the science (2nd ed.), ( pp. 125-164). New Jersey: Erlbaum.

68) Roberson, Q. and Park, H. (2007). Examining the link between diversity and firm performance: The effects of diversity reputation and leader racial diversity. Group \& Organization Management, 32, 548-568.

69) Robson, C., 2002. Real World Research: A resource for social scientists and practitionerresearchers $\left(2^{\text {nd }}\right.$ ed.). Oxford, UK: Wiley Blackwell.

70) Rosen, R., Digh, P., Singer, M., \& Phillips, C. (2000). Global literacies: Lessons on business leadership and national cultures. New York, NY: Simon \& Schuster.

71) Rost, J. C. (1992). Leadership for the twenty-first century. New York, NY: Praeger.

72) Saunders, M., Lewis, P. \& Thornhill, A., 2009. Research Methods for Business Students $\left(5^{\text {th }}\right.$ Ed.), London, U.K: Financial Times Prentice Hall.

73) Schein, E. H. (2004). Organizational culture and leadership (3rd ed.). New York, NY: Jossey-Bass.

74) Schein, H. E. (2011). What is culture?. In M. Goodyan and J. Gittell (Ed.). Sociology of 271 organisations structures and relationships, (pp. 311-314). London: SAGA.

75) Trompenaars, A., \& Hampden-Turner, C. (1998). Riding the waves of culture: Understanding cultural diversity in global business (2nd ed.). New York, NY: McGraw-Hill.
76) Van der See, K.I., \& van Oudenhoven, J.P. 2001. The multicultural personality questionnaire: Reliability and validity of self and other ratings of multicultural effectiveness. Journal of Research in Personality, 35(3), 278-288. Doi:10.1006/jrpe.2001.2320

77) Vanderpool, M. 2002. The Cross-cultural Adaptability Scale: A comparison of the psychometric properties observed in a Canadian and an Australian administration (Sponsor Research Report 2002-07). Ottawa, Ontario: Human Resources Research and Evaluation.

78) Wen-Cheng, W., Chien-Hung, L. and Ying-Chien, C. (2011). Cultural diversity and information and communication impacts on Language Learning. International Education Studies, 4 (2), 111-115.

79) Wunderle, W. D. (2008). Through the lens of cultural awareness: A primer for US armed forces deploying to Arab and Middle Eastern countries. Fort Leavenworth, KS: Combat Studies Institute Press.

80) Yukl, G. (2002). Leadership in Organisation (5th ed.). Upper Saddle River, NJ: Prentice Hall.

81) Yukl, G. A. (2006). Leadership in organizations (6th ed.). Upper Saddle River, NJ: Pearson/Prentice Hall.

82) Zayani, F. A., 2008. The impact of transformational leadership on the success of global virtual teams: An investigation based on the multifactor leadership questionnaire. (Doctoral dissertation). Minneapolis, MN: Capella University. 